\title{
Model Proportion of Expertise Competence As Industry Recommendation In Industrial Selection Practice Program
}

\author{
Novianto Yudha Laksana, Ratna Wardani \\ Educational of Electronics and Informatics Engineering, \\ Postgraduate Program. \\ Universitas Negeri Yogyakarta \\ Yogyakarta, Indonesia \\ novianto.yudha2015@student.uny.ac.id
}

\begin{abstract}
This research aims for developing and implementing the proportion of field competency model that can be used as Industrial Market recommendation for determining the result of industrial practice selection that is appropriate with the criteria. The development design was grouped into three developmental procedures, consisting of: (a) preliminary study, (b) development study and (c) evaluation. There are seven expert test subjects which consisting of Human Resource Development (HRD) staff and engineers. The system test subjects are ten students who will do industrial practice in PT. Gamatechno Indonesia. Data collection techniques used questionnaires, direct observation and interviews. Data analysis technique used hierarchy Analytical Hierarchy Process (AHP) approach. approach created of 3 criterias, 13 subcriterias and 5 alternative job sectors. Each criteria were calculated by pairwise comparison resulting in a priority weight. The ratio consistence calculation for each criteria shows less than 0.1 so it is concluded that the priority weight is consistent and acceptable. The testing is executed with the comparison of the calculation result from developed decision support system. In this testing, the inputted data is from the student's assessment toward each criteria. The comparison result shows that the developed AHP approach model is running well.
\end{abstract}

Keywords-competence propotional, AHP, decision support system

\section{INTRODUCTION}

Vocational High School is fully responsible in educating their students and obliged to maintain the continuity of apprenticeship program to run well. In addition, the school also has hope and purpose for the output of this apprenticeship program can improve student competence as desired by the school. Based on the observation and experience of the researcher when conducting the survey, there are many inconsistencies between the competencies that students learn in Vocational High School with what students do when apprenticeship. In addition, Muhadjir Effendy in Bona Maria [1] says that many companies consider apprentices to be unpaid laborers and treated only out of necessity. Batubara in Soenarto [2] adds that there is a gap between industrial demand for labor with the type and quality of vocational school graduates. Technological advances in industrial develop faster than the readiness of educational institutions in planning and implementing curriculum, methods, and provision of facilities and infrastructure that should be owned by educational institutions in order to produce graduates who are ready to enter the workforce. So as to seem stuck and there is no continuity between the theory received in school and the practice required in the workplace [3].

On the other hand, most industries do not have a recruitment standard for admission to the apprenticeship program yet. So, in the implementation still impressed, imposed and formality only. In the industry there are not many who apply the special selection process for the admission of apprenticeship students because it is basically the focus of the industry is the use of ready-made human resources. But if investigated further, not a few apprenticeship students who have the ability above average and ready to use so that indirectly can help the production process in the industry. Meanwhile, the industry needs recommendations or supporting tools in the process of selection of industrial practices so as to minimize the competence of students who wasted in vain.

Therefore, the effort to prepare students before implementing apprenticeship should be done so that the implementation of apprenticeship run well and not impressed imposed. The school should know the industryspecified competency standards on Vocational High School students to be used as input in preparing their students. There should be a suitability between the required capabilities of the industry and the capabilities that schools must prepare, so that apprenticeship implementation takes place in accordance with the original objectives, and no party is harmed. There are several issues to be outlined in this paper as the following:

- How to determine the proportion of competence models for industrial recommendations in the selection process of industrial practice.

- How is the proportion of competence model developed prototype for industrial recommendation in production selection process through decision support system approach. 
- Basic Literacy Skill: A basic skill that everyone should definitely have like reading, writing, math and listening.

\section{A. Vocational Education}

According to Pavlova [9], vocational education is education that prepares students to be ready to work. The role of vocational education is very strategic in preparing prospective workers who have certain professional skills to obtain the field of work in accordance with its specialization. Billett [2] said vocational education has four important goals, including: (1) preparation for work on individuals including informing them about their positions in employment; (2) early preparation for individual work life including developing the capacity to practice on the job chosen; (3) sustainable development for individuals throughout their lives to be able to work from time to time; (4) an educational experience that supports the transition from one work to another either selected or coerced. Amankwah and Swanzy [5] said there is also need for involvement and collaboration between vocational high school, government, and industry so that the competence of students in accordance with the world of work.

\section{B. Competence in Education}

Based on MacKenzie [8] key competencies are one of several common skills or competencies considered important for people to be able to participate effectively in the workforce. Key competencies apply to work in general, not specific to work in a particular job or industry. Furthermore, according to Kipral [7] individual competence should be developed in a way that supports between the work and business context so that they can be more flexible on different working situations.

According to Veal [14] competence has become popular as a way of measuring output (student learning outcomes). The concept of competence is a set of skills used for skills certification and the outcome of learning (the process of acquiring competence and qualifications). Competence is the key word of the educational process especially for vocational school.

\section{Proportion of Competence Area Expertise}

Proportion is a very common word used in everyday life and familiar in the community. The term proportion is more widely known and used in the discipline of statistics to describe the (percentage) portion of a particular occurrence of the entire data. In general, the proportion is the ideal and harmonious comparison between the parts of the object being the object, or the other terms are balanced. The proportion of competencies further illustrates a balance between knowledge, skills and attitudes. In the world of work, knowledge, skills and attitudes are the basic parameters that are the foundation of the recruitment process. According to Notoatmodjo in Clara Devinta [4], 'knowledge' is the result of knowledge from humans who simply answer the question "What". Knowledge is the result of a sense of curiosity and this occurs after the person does the sensing of a particular object. Sensing, smell, taste and touch. Knowledge or cognitive is a very important domain in shaping one's actions. According to Dunette in Clara Devinta [4] skill means developing the knowledge gained through training and experience by carrying out several tasks:
- Technical Skill: Technical expertise gained through learning in engineering such as computer and other digital devices.

- Interpersonal Skill: Everyone's expertise in communicating with each other is like listening to someone, giving opinions and working on a team basis.

- Problem Solving: A person's expertise in solving problems using his logic.

These three parameters are very important functions and roles in the development of an industrial world. In other words, it can be concluded that the balance of knowledge, skills, and attitudes possessed by individuals will be influential in the progress of the industry where work.

\section{Multi Criteria Decision Making (MCDM)}

Decision support system is a computer-based interactive system that can help make decisions by utilizing data and models to solve unstructured problems by Turban [13]. Multi Criteria Decision Making (MCDM) is a decisionmaking method to establish the best alternative of a number of alternatives based on certain criteria. MCDM has two categories: Multiple Objective Decision (MODM) and Multiple Attribute Decision Making (MADM). Multiple Objective Decision Making (MODM) is a method by taking many criteria as the basis of decision making which includes design problems, in which mathematical techniques for optimization are used and for a very large number of alternatives (up to infinity). While Multiple Attribute Decision Making (MADM) is a method by taking many criteria as the basis for decision making, with subjective judgments regarding the selection problem, where the mathematical analysis is not too much and is used for the selection of small alternatives.

There are several methods that can be used in solving MCDM problems, among others:

- Simple Additive Weighting Method (SAW)

- Weighted Product (WP)

- Axiomatic Design

- ELECTRE

- Technique for Order Preference by Similarity to Ideal Solution (TOPSIS)

- Analytic Hierarchy Process (AHP)

\section{E. Analytic Hierarchy Process (AHP)}

AHP is a decision support model developed by Thomas L. Saaty. This decision support model describes complex multi-factor or multi-criteria problems into a hierarchy. A complex problem can be defined as the criteria of a multicriteria, the uncertainty of the problem structure, the uncertainty of opinion from the decision-maker, the decision maker of more than one person, and the inaccuracy of available data. According to Saaty [11], a hierarchy is defined as a representation of a complex problem in a multilevel structure where the first level is the goal, followed by the factor level, criteria, sub criteria, and so on down to the last level of the alternative. With a hierarchy, a complex problem can be broken down into groups that are then 
organized into a hierarchical form so that the problem will seem more structured and systematic.

AHP is often used as a problem-solving method compared to other methods for the following reasons:

- The hierarchical structure, as a consequence of the selected criteria, to the deepest subcriteria.

- Takes into account the validity up to the limit of inconsistency tolerance of the various criteria and alternatives chosen by the decision maker.

- Taking into account the endurance of output sensitivity analysis of decision making.

In addition, the AHP method has the ability to solve multi-objective and multi-criteria problems based on the preference comparison of each element in the hierarchy. So, the AHP method is a very comprehensive form of decisionmaking model.

The stages of decision making with the AHP method are as follows:

1. Develop a hierarchy of problems encountered. Issues that will be resolved, broken down into its elements, namely criteria, sub-criteria and alternatives.

2. Pairwise comparison criteria. Criteria and alternatives are assessed through pairwise comparisons. According to Saaty [12], for various issues, the scale 1 to 9 is the best scale in expressing opinions. The value and definition of qualitative opinion from the comparison scale of Saaty can be seen in Table 1

TABLE I. LEVEL OF INTER-CRITERIA INTERESTS LEVEL

\begin{tabular}{|c|c|c|}
\hline Scale & Definition & Explanation \\
\hline 1 & $\begin{array}{l}\text { Both elements are equally } \\
\text { important }\end{array}$ & $\begin{array}{l}\text { Two elements have a weight } \\
\text { that is worth the value }\end{array}$ \\
\hline 3 & $\begin{array}{l}\text { A weak element of the value } \\
\text { of its importance to the other }\end{array}$ & $\begin{array}{l}\text { Experience and judgment } \\
\text { rather like an element than } \\
\text { others }\end{array}$ \\
\hline 5 & $\begin{array}{l}\text { An essential or more } \\
\text { important element to the } \\
\text { other }\end{array}$ & $\begin{array}{l}\text { Experiences and judgments are } \\
\text { stronger in favor of an element } \\
\text { than others }\end{array}$ \\
\hline 7 & $\begin{array}{l}\text { Showing an element is more } \\
\text { important than others }\end{array}$ & $\begin{array}{l}\text { A stronger element is favored } \\
\text { and its dominance is apparent } \\
\text { in its true state }\end{array}$ \\
\hline 9 & $\begin{array}{l}\text { Absolutely an element is } \\
\text { more important than others }\end{array}$ & $\begin{array}{l}\text { The fact that an element is } \\
\text { preferred over the other is at } \\
\text { the highest possible in a } \\
\text { known sequence }\end{array}$ \\
\hline
\end{tabular}

3. Consistency Analysis. All elements are grouped and recorded consistently in accordance with predetermined criteria. Consistency calculation is done by following the steps as follows:

- Calculates the value of eigen value $(\lambda \max )$ by summing the value per column of pairwise comparison matrices.

- Calculates the consistency index

- Calculates the consistency ratio. If the consistency ratio is $\leq 0.1$, the calculation of the criterion comparison can be justified

\section{RESULT AND DISCUSSION}

\section{A. Design of The Development Model}

Based on Presmann's prototyping research method [10], researchers describe the model description of the proportion of expertise in the field of expertise in the diagram as follows:

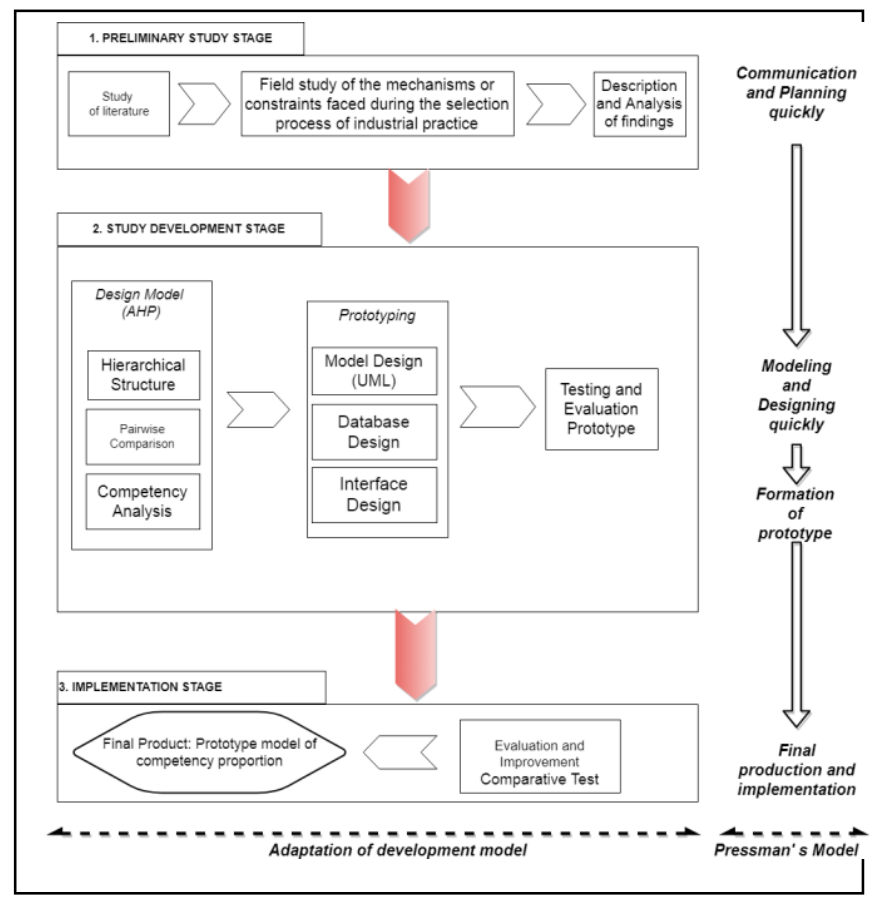

Fig. 1. Research and Development Research Stage

Stages of research on the development of the proportion of competence models as industrial recommendations in the selection process of this industry practice using the procedure through three stages, namely:

1. The preliminary study phase, is a pre-survey stage (initial stage), where the activities undertaken are as follows:

a. Assessing the theories relating to vocational education, the proportion of competencies and industrial practices,

b. Assessing the results of previous research which is closely related to the proportion of competence models and system development using the AHP method,

2. Stage of development study, is a procedure performed in the second stage that includes:

a. Modeling, is determining the proportion model based on the AHP method, stages include: hierarchy, criteria and alternatives assessment, prioritization and logical consistency,

b. Trial and evaluation of developed models,

c. Prototyping model, the process of implementing the model into a prototype, the stages include UML modeling, interface design and encoding using PHP

d. Testing and evaluation of prototype related functionality of groove model developed 
3. Evaluation phase, at this stage that is done is:

a. Comparative test, is testing the model and prototype with the specified subject and comparing the results,

b. Evaluation and refinement.

\section{B. Hierarchical Structure}

Based on the preliminary stage of the preliminary study, the results of the survey, criteria and alternatives have been determined to be used in the proportion of competence models as industrial recommendations in the selection process of industrial practice. The next step is to create a hierarchical structure based on criteria and alternatives in accordance with Figure 2.

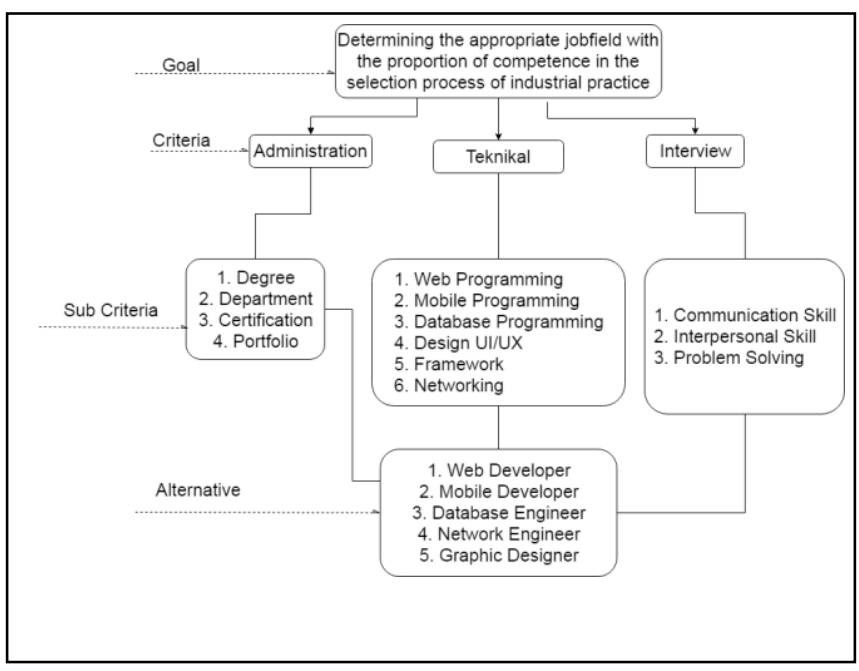

Fig. 2. Structure Hierarchy Model Proportion of Competence

\section{Pairwise Comparison}

A pairwise comparison is performed between each criterion with each alternative, each subcriteria with each alternative. Data obtained from questionnaires filled by expert sources.

TABLE II. MATCHED COMPARISON MATRICES CRITERIA

\begin{tabular}{|c|c|c|}
\hline Criteria/subcriteria & value of root result & Priority Weight \\
\hline Adminitration & $0.333 / 4.10$ & 0.081 \\
\hline Technical & $2.621 / 4.10$ & 0.639 \\
\hline Interview & $1.145 / 4.10$ & 0.279 \\
\hline Degree & $0.408 / 5.875$ & 0.069 \\
\hline Department & $0.435 / 5.875$ & 0.074 \\
\hline Certificate & $3.350 / 5.875$ & 0.570 \\
\hline Portfolio & $1.682 / 5.875$ & 0.286 \\
\hline Web programming & $2.655 / 7.66$ & 0.347 \\
\hline Mobile programming & $0.365 / 7.66$ & 0.048 \\
\hline Database & $0.765 / 7.66$ & 0.1 \\
\hline Design & $1.201 / 7.66$ & 0.157 \\
\hline Framework & $2.154 / 7.66$ & 0.281 \\
\hline Network & $0.521 / 7.66$ & 0.068 \\
\hline Communication & $0.585 / 3.744$ & 0.156 \\
\hline
\end{tabular}

\begin{tabular}{|c|c|c|}
\hline Criteria/subcriteria & value of root result & Priority Weight \\
\hline Interpersonal & $0.693 / 3.744$ & 0.185 \\
\hline Problem solving & $2.466 / 3.744$ & 0.659 \\
\hline
\end{tabular}

\section{Consistency Analysis}

The consistency analysis stage is done by calculating Consistency Ratio (CR) from pairwise matrix matrix criteria. If $\mathrm{CR}>0.1$ then it must be repeated pairwise comparison until $\mathrm{CR}$ value $<0.1$.

1. Calculate the eigenvalue or $\lambda$ matrix

TABLE III. $\Lambda$ MAX CALCULATION OF MATRIX OF INTEREST COMPARISON BETWEEN CRITERIA

\begin{tabular}{|l|c|c|c|}
\hline \multicolumn{1}{|c|}{ Criteria } & Administration & Technical & interview \\
\hline Administration & 1.00 & 0.11 & 0.33 \\
\hline Technical & 9.00 & 1.00 & 2.00 \\
\hline interview & 3.00 & 0.50 & 1.00 \\
\hline Total & 13.00 & 1.61 & 3.33 \\
\hline $\begin{array}{c}\text { The Total } \\
\text { Priority Value } \\
\text { of X }\end{array}$ & 1.057 & 1.03 & 0.931 \\
\hline $\boldsymbol{\lambda}$ max & \multicolumn{3}{|c}{$\mathbf{3 . 0 1 8}$} \\
\hline
\end{tabular}

2. Calculating Consistency Index. After obtaining $\lambda$ max then calculation is done to obtain consistency index $(\mathrm{CI})$

TABLE IV. RESULT OF CONSISTENCY INDEX OF EACH CRITERIA

\begin{tabular}{|c|c|c|}
\hline Criteria/subcriteria & $\lambda \max$ & CI \\
\hline Adminitration & \multirow{3}{*}{3.018} & \multirow{3}{*}{0.009} \\
\hline Technical & & \\
\hline Interview & & \\
\hline Degree & \multirow{4}{*}{4.006} & \multirow{4}{*}{0.002} \\
\hline Department & & \\
\hline Certificate & & \\
\hline Portfolio & & \\
\hline Web programming & \multirow{6}{*}{6.109} & \multirow{6}{*}{0.022} \\
\hline Mobile programming & & \\
\hline Database & & \\
\hline Design & & \\
\hline Framework & & \\
\hline Network & & \\
\hline Communication & \multirow{3}{*}{3.029} & \multirow{3}{*}{0.015} \\
\hline Interpersonal & & \\
\hline Problem solving & & \\
\hline
\end{tabular}

\section{Calculating Consistency Ratio}

After consistency index value (CI) is obtained, then calculation of consistency ratio (CR). Based on the size of the matrix of each criteria, the random index (RI) value used refers to Table 5 . 
TABLE V. THE RESULT OF THE CONSISTENCY RATIO OF EACH CRITERIA

\begin{tabular}{|c|c|c|c|}
\hline Criteria/subcriteria & CI & $R I$ & $C R$ \\
\hline Adminitration & \multirow{3}{*}{0.009} & \multirow{3}{*}{0.58} & \multirow{3}{*}{0.016} \\
\hline Technical & & & \\
\hline Interview & & & \\
\hline Degree & \multirow{4}{*}{0.002} & \multirow{4}{*}{0.9} & \multirow{4}{*}{0.002} \\
\hline Department & & & \\
\hline Certificate & & & \\
\hline Portfolio & & & \\
\hline Web programming & \multirow{6}{*}{0.022} & \multirow{6}{*}{1.24} & \multirow{6}{*}{0.018} \\
\hline Mobile programming & & & \\
\hline Database & & & \\
\hline Design & & & \\
\hline Framework & & & \\
\hline Network & & & \\
\hline Communication & \multirow{3}{*}{0.015} & \multirow{3}{*}{0.58} & \multirow{3}{*}{0.025} \\
\hline Interpersonal & & & \\
\hline Problem solving & & & \\
\hline
\end{tabular}

\section{E. Testing and Evaluation Model}

Based on the steps that have been done in model design, testing is done to know the functionality and evaluate the findings. In the first step, the problem to be solved, described into its elements namely, criteria, sub criteria and alternatives, then compiled into a hierarchy structure.

Next the priority weight of each criterion is calculated based on the result of paired comparison for each assessment given by the expert. Judging from the calculation of weight, the "technical" criteria has the highest value compared to other criteria.

The last step, to calculate the consistency of priority weighting is done by comparing the consistency index to the random index. The result obtained is the value of consistency ratio less than 0.1 . So it can be said that the calculation of weight is acceptable and consistent.

\section{CONCLUSION}

The conclusions that can be given based on the results and the discussion and testing model of determining the proportion of competencies in the selection of industrial practice programs through the AHP approach are as follows:

1. Model of competency proportion as industrial recommendation in selection of industrial practice program has been developed and implemented in the form of system prototype. The detailed model developed is as follows: a) The model was developed by AHP method using 3 criteria, 13 sub-criteria and 5 alternatives.

b) To produce a model of competency proportion, each criterion is formulated based on AHP steps, is arranging hierarchy, pairwise comparisons and consistency testing

c) The model is implemented into prototype of a webbased system with prototype development method, is system requirement analysis, design concept, coding, testing and evaluation.

2. Based on the test results, AHP method is an appropriate method to model the proportion of job competence as an industrial recommendation in the selection of industrial practice programs.

\section{REFERENCES}

[1] Bona Maria. (2017). Siswa Magang Jangan Hanya Disuruh Bukin Kopi. Accessed 24th November 2017 from http://www.beritasatu.com/kesra/419166-mendikbud-siswa-magangjangan-hanya-disuruh-bukin-kopi.html

[2] Soenarto.(2003). Kilas Balik dan Masa Depan Pendidikan dan Pelatihan Kejuruan. Professorship Inaugural Speech. UNY : Yogyakarta.

[3] Subarkah. (2007).Vocational Education Global Development Center. Semarang: Graduate program (S3) Unnes

[4] Devinta, Clara. (2015). Knowledge, Skill, dan Attitude Dalam Dunia Kerja. Accessed 28th Desember 2017, from https://id.linkedin.com/pulse/knowledge-skill-dan-attitude-dalamdunia-kerja-consulting-group

[5] Amankwah, E. and Swanzy, P. The Role of Stakeholders in Building Adequate Competences in Students for the Job Market. International Journal of Vocational and Technical Education, 2011, pp. 107-112.

[6] Billett, S. Vocational education purposes, traditions and prospects. London: Springer Science Business Media, 2011.

[7] Kipral, S.R. Labour-Market Flexibility and Individual Careers A Comparative Study. London: Springer Science Business Media, 2011.

[8] MacKenzie, J. and Polvere R.A. TVET Glosary: Some Key Terms. In Rupert Maclean, David Wilson, Chris Chinien (Eds.), International handbook of education for the changing world of work, bridging academic and vocational learning, 2009, pp. 59-76. Bonn: Springer Science Business Media

[9] Pavlova, M. Technology and vocational education for sustainable development empowering individuals for the future. Queensland: Springer, 2009.

[10] Pressman, R.S, Software Engineering : a practitioner's approach, McGraw-Hill, New York, pp 68, 2010.

[11] Saaty, Thomas L. Decision making with the analytic hierarchy process International Journal Services Science, Vol. 1, No. 1, 2008.

[12] Saaty, T. \& Vargas,L. Models, Methods, Concepts and Application of TheAnalytic Hierarchy Process, Sepringer Science Business New York, Second Edition, 2012.

[13] Turban, E., Aronson, J. E., \& Liang, T. P. Decision Support Systems and Intelligent System 7th Edition. New Delhi: Prentice Hall, Inc, 2005.

[14] Veal, K. Overview: Competencies, Qualifications and Recorgnition. In Rupert Maclean, David Wilson, Chris Chinien (Eds.), International handbook of education for the changing world of work, bridging academic and vocational learning, 2009, pp. 2763-2776. Bonn: Springer 